\title{
An Empirical Assessment of Digital Library Service: Perspective of DeLone and McLean Information System Success Model
}

\author{
Hui Li Gao \\ School of Foreign Studies \\ Northwestern Polytechnical University \\ Xi'an, China
}

\begin{abstract}
Digital book information services have gradually been valued and relied on. Users can use computers to obtain the required information anytime, anywhere, greatly improving the convenience of reading and research. The purpose of this study is to analyze the current use of Digital Library Service by domestic university students, and to explore the influencing factors for the use of Digital Library Service by Chinese college students based on the theoretical framework of the DeLone and McLean Information System Success Model. This study first explores the importance of Digital Library Service in the field of university education and the implications and goals of the school administration system. Next, a questionnaire for this research was prepared based on the Information System Success Model framework, and a questionnaire survey was conducted for college students using Digital Library Service in China. Finally, the statistics and analysis of the recycling questionnaire were conducted. The analysis results of this study found that information quality and service quality have a positive and significant impact on satisfaction. In addition, information quality and service quality have an indirect influence on the continued use of Digital Library Service through satisfaction. However, system quality did not have a significant impact on the Digital Library Service. Based on the above conclusions, the researchers put forward suggestions for education administrative agencies, school units and future researchers, with a view to providing references for education administrators, university staff and related research.
\end{abstract}

Keywords: Digital Library Service; E-Portfolio; DeLone and McLean Information System Success Model; System Quality; Information Quality; Service Quality

\section{Introduction}

With the advancement of information technology, the university's administrative information system has been increasingly affected by the digital environment since the late 20th century.Due to the rise of the global information network, domestic libraries have to gradually abandon the traditional search system model and use the emerging Internet system to provide services. The emergence of online bookstores and search engines such as Baidu Scholar, Amazon, etc. has led to the reform of library information technology.At the end of 2004, a plan to digitize the collection of books was named Google Print for Library, or Google Library for short. Launched in partnership with the Google search engine website.

Digital book information services have gradually been valued and relied on. Users can use computers to obtain the required information anytime, anywhere, greatly improving the convenience of reading and research. The information system built by the digital library can store a large amount of knowledge and provide information retrieval and use of digital content. It is an important bridge between human information needs and digital book information. The purpose of this study is to analyze the current use of Digital Library Service by domestic university students, and to explore the influencing factors for the use of Digital Library Service by Chinese college students based on the theoretical framework of the DeLone and McLean Information System Success Model.

\section{Literature Review}

\subsection{DeLone and McLean information system success model}

In 1992, DeLone and McLean reviewed 180 articles that depended on the effectiveness of information systems, combined with the results of many empirical studies, and proposed a method to measure the success model of information systems. They developed the "Information System Success Model" System Success Model) and incorporates information quality and system quality into the assessment of information system success models.It is proposed in the model that system quality and information quality will affect the use of the information system and user satisfaction. The use of the information system and user satisfaction will cause personal Impact, the use of information systems and user satisfaction will have an individual impact, and then an organizational impact.Pitt, Watson, and Kavan (1995) believe that measuring the effectiveness of information systems is multi-faceted, while the model of Delone and Mclean (1992) is only a part, and most of them usually measure the system itself more than services, so their view is product Orientation (functions provided by the system and output of information content), Pitt pointed out that in terms of information departments, in addition to products, the quality of services should also be included. 
These services include software and hardware installation, support and education, and Internet Therefore, when measuring the models of Delone and Mclean, we should add the item of service quality to this model.

DeLone and McLean revised their information system success model proposed in 1992 in 2003 . They joined Pitt in 1995 and put forward the idea of service quality based on the original IS Success Model. The revised model is shown in Figure 2. This proposed model is divided into six evaluation indicators, which are information quality, system quality, service quality, system use, user satisfaction, and net benefits. Six evaluation indicators to measure the success of the information system, the system benefits are measured by the feedback relationship between system use, user satisfaction, and system benefits, and they are regarded as the success indicators of the information system.

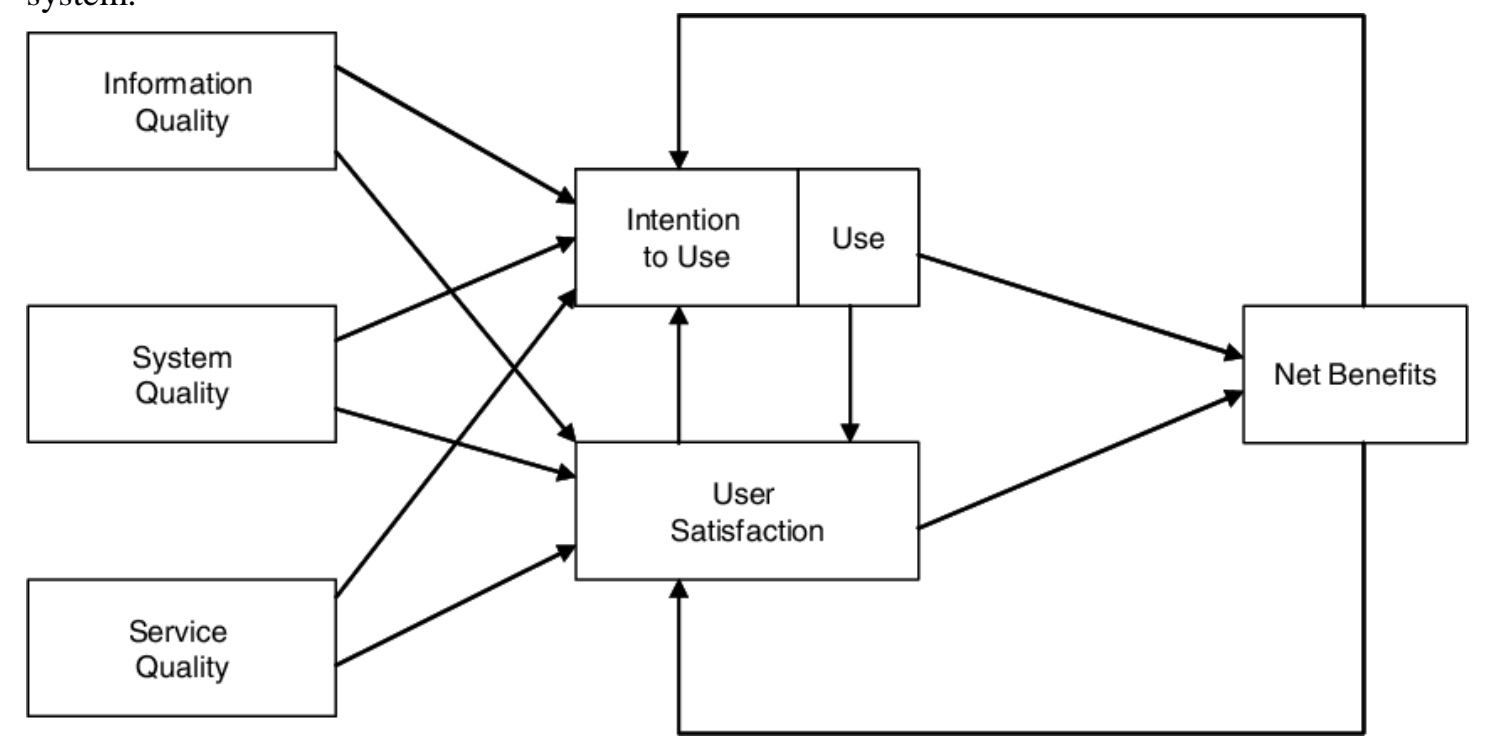

Figure 1: Delone-Mclean Information System Success Model

Earlier academic research believed that the quality of service originated from the comparison of the customer's perception of the service provided by the company with the actual service performance of the company (Lewis and Booms, 1983; Parasuraman et al., 1985).Parasuraman et al. (1991) used the multi-item measurement method to evaluate the company's service quality from the user's point of view, and conducted empirical research in various industries. Aspects of service quality such as sexuality and empathy.Therefore, the service quality in this study includes tangibility, reliability, responsiveness, assurance, and emotion.System use and willingness (Use) Assess the user's use of the information system, including the use time, characteristics, degree of use, voluntary use, re-use, etc.User Satisfaction evaluates the user's response to the output of the information system, including software satisfaction, information satisfaction, decision satisfaction, and overall system satisfaction.Net Benefit The impact on the performance of an organization. The measurement items include improving organizational productivity, improving service quality, improving organizational image, saving manpower, reducing organizational operation costs, shortening the time for transmitting data between organizations, increasing income, and so on. In terms of measuring digital library information services, research by Thong, Hong, and Tam (2002) indicates that the average library reader believes that the use of digital library systems will improve their academic achievements and make academic and research completion more complete. Efficiency, improve research performance, and facilitate preparation for academic exams. Table 1 lists related research on past information system success models.

Table 1: Relevant Studies of DeLone-McLean Information System Success Model

\begin{tabular}{lll}
\hline \multicolumn{1}{c}{ Author } & \multicolumn{1}{c}{ Research Topics } & \multicolumn{1}{c}{ Source } \\
\hline \hline $\begin{array}{l}\text { Gorla, N., Somers, T. } \\
\text { M., \& Wong, B. }\end{array}$ & $\begin{array}{l}\text { Organizational impact of system quality, } \\
\text { information quality, and service quality. }\end{array}$ & $\begin{array}{l}\text { Journal of Strategic } \\
\text { Information } \\
\text { Systems }\end{array}$ \\
\hline \hline $\begin{array}{l}\text { Aldholay, A. H., Isaac, } \\
\begin{array}{l}\text { O., Abdullah, Z., } \\
\text { \&Ramayah, T. }\end{array}\end{array}$ & $\begin{array}{l}\text { The role of transformational leadership as a } \\
\text { mediating variable in DeLone and McLean } \\
\text { information system success model: The } \\
\text { context of online learning usage in Yemen. }\end{array}$ & $\begin{array}{l}\text { Telematics and } \\
\text { Informatics }\end{array}$ \\
\hline
\end{tabular}




\begin{tabular}{lll}
\hline \multicolumn{1}{c}{ Author } & \multicolumn{1}{c}{ Research Topics } & \multicolumn{1}{c}{ Source } \\
\hline \hline & & Journal of \\
$\begin{array}{l}\text { Almutairi,H.,\& } \\
\text { Subramanian, G. H. }\end{array}$ & $\begin{array}{l}\text { An empirical application of the DeLone and } \\
\text { McLean model in the Kuwaiti private sector. }\end{array}$ & $\begin{array}{l}\text { Computer } \\
\text { Information } \\
\text { Systems }\end{array}$ \\
\hline \hline & & Journal of \\
Angelina,R.J., & Analyzing E-Commerce Success using & Information \\
Hermawan,A.,\&Suroso, & Systems \\
A. I. & DeLone and McLean Model. & Engineering and \\
& & Business \\
\hline \hline
\end{tabular}

Bernroider, E. W.

IT governance for enterprise resource planning supported by the DeLone-McLean model of information systems success.

Information \&

Management

Understanding consumer intention in online shopping: a respecification and validation of the DeLone and McLean model.
Behaviour\&

Information

Technology

Cheng, C. Y. J

Acceptance and satisfaction of learning management system enabled blended learning

Ghazal, S., Aldowah, H., Umar, I., \&Bervell, B. based on a modified DeLone-McLean information system success model.
International Journal of Information Technology Project Management

The Journal of Strategic Information Systems

Global Business \& Management Research

International Journal of Sociotechnology and Knowledge Development (IJSKD)

Journal of Computer Information Systems

International Journal of Economics and Financial Issues
Mardiana, S., Tjakraatmadja, J. H., \&Aprianingsih, A.
DeLone-McLean information system success model revisited: the separation of intention to use-use and the integration of technology acceptance models.
Healthcare informatics research
Validation of the DeLone and McLean information systems success model. 


\begin{tabular}{lll}
\hline \multicolumn{1}{c}{ Author } & \multicolumn{1}{c}{ Research Topics } & \multicolumn{1}{c}{ Source } \\
\hline \hline $\begin{array}{l}\text { Wang, Y. S., \& Liao, } \\
\text { Y. W. }\end{array}$ & $\begin{array}{l}\text { Assessing eGovernment systems success: A } \\
\text { validation of the DeLone and McLean model } \\
\text { of information systems success. }\end{array}$ & $\begin{array}{l}\text { Government } \\
\text { information } \\
\text { quarterly }\end{array}$ \\
\hline \hline $\begin{array}{l}\text { Wei, K. M., Tang, Y. } \\
\text { T., Kao, Y. C., Tseng, } \\
\text { L. C., \& Wu, H. H. }\end{array}$ & $\begin{array}{l}\text { Using an updated Delone and McLean model } \\
\text { to assess the success of implementing the ward } \\
\text { cleaning logistics system in a medical center. }\end{array}$ & $\begin{array}{l}\text { Journal of Statistics } \\
\text { and Management } \\
\text { Systems }\end{array}$ \\
\hline
\end{tabular}

\subsection{Information quality}

Information is one of the elements that make up a website. The higher the quality of the information, the better the quality of the website. Wang and Strong (1996) pointed out from a systematic perspective that professional information systems are not only about improving the accuracy of data, but also considering the acceptability of data and the relevance of data.Tayi and Ballou (1998) believe that the best definition of information quality is "fitness for use". Rai, Lang, and Welker (2002) defined information quality as a measure of information system output. McKinney, Yoon, and Zahedi (2002) define the quality of information as the generated information has the content, correctness, and format that meets user needs.Users expect the quality of the information provided by the site to be clear, readable, reliable, and accurate. Eppler and Muenzenmayer (2002) classifies information quality into content quality (easy to understand, clear, accurate, correct, concise, usable, consistent, up-to-date) and media quality (interactive, secure, instant, accessible, maintainable, traceable, fast).Jeong and Lambert (2001) analyzes the user behavior of the website and develops an information quality framework for the website behavior. This framework is the demand for information and results in the quality of the information, which in turn affects the users 'wishes and their actual use behavior. In the past, scholars believed that the definition of information quality and the trend of modern websites found that in the definition of many scholars, information systems focus on the quality of information system output, such as statements produced by information systems, rather than focusing on the quality of information Measurement of efficacy (Rai et al. 2002; Eppler \&Muenzenmyer, 2002).

The earliest information quality was used in library management systems and accounting information systems to evaluate the correctness and real-time information output of reports. Later, scholars gradually applied information quality to virtual platform applications such as online shopping and e-commerce. In the past, with the development of the Internet, the number of people using online services has gradually increased. Therefore, good platform information can be accepted by users, and they are willing to share their experience with others. Therefore, the establishment of good information quality is One of the first keys.

\subsection{System quality}

Sigwart (1990) and others divided the system quality into 15 factors including reliability, efficiency, maintainability, modifiability, portability, and usability. The balance of system quality usually focuses on system performance. For example, Guynes and Pelley (1993) suggested that the use of asset database system performance should be adjusted using software and hardware monitoring tools.Some researchers have discussed the response time, stability, accessibility, accuracy, integrity, and tolerance of use (Bailey and Pearson, 1983; Doll and Torkzadeh, 1988; Ives et al., 1983; Doll et al., 1994).Some researchers have explored the impact of user involvement (Bailey and Pearson, 1983; Ives et al., 1983).System quality description systems that involve " defects " include system reliability, user interface consistency, usability, quality of content, and quality and maintainability of program source code (Seddon, 1997; Gorla \& Lin, 2010).

\subsection{Service quality}

Parasuraman et al. (1988) believe that the gap between service and focus on service performance is service quality. The study believes that service quality is one of the main reasons for improving customer satisfaction. It targets the industries such as long-distance telephone companies, material repairs, credit cards, and banking, and the results of in-depth interviews with supervisors and their customer interviews. After factor analysis, the five facets and 22 scales developed by the Institute are called SERVQUAL scales, and some modifications to the information system were introduced by Pitt et al. (1995) to become suitable for scale information services.

Therefore, the success of the Hengye Information System is only a manifestation of the product itself, and can include service quality such as software and hardware installation, support, education and training, and network quality.Delone and Mclean (2003) succeeded in the information system, and the new model increased the aspect of service quality, standardizing the standard of service quality, including guarantee, consideration, and responsiveness.In addition, studies evaluating the evaluation of information systems related to internet shopping have pointed out that the elements of service quality are related factors such as clarity, reliability, enthusiasm, assurance, empathy, and communication (Long and McMellon, 2004). 


\section{Methodology}

According to the compilation and discussion of the above-mentioned related literatures, this study considers that digital libraries are an information system itself. Therefore, the information system success model can be used as an important infrastructure to explore the factors and performance of digital libraries, and then include satisfaction and continuity intention Developed a user satisfaction and performance evaluation model based on Digital Library Service (see Figure 2).This research proposes a research hypothesis based on the above research framework (as shown in Table 2).

In this study, a questionnaire survey was used to collect the opinions of the research subjects.With reference to the definitions and questionnaires of relevant literature, the questionnaire content of this research was prepared, and then a scholar with a background in the field of library information and a master's degree student in the Department of Information Management conducted a pretest to test the terminology of the research questionnaire. Is it clear and clear, to avoid those who fill in the question because the meaning of the questionnaire are ambiguous.

In terms of research analysis tools, this study used SPSS24 and SmartPLS 3.2.9 (Ringle et al., 2019) for statistical analysis. The contents of this study are as follows: (1) Reliability analysis: measure the credibility or stability of the questionnaire results in the questionnaire, and use Cronbach's $\alpha$ and Composite Reliability for internal consistency analysis; (2) validity analysis: test questionnaires The ability to measure, that is, the validity of the questionnaire measurement, the detection of validity includes convergence validity and differential validity; (3) Path analysis: Calculate the Path Coefficient between related aspects of the research model to verify Investigate whether the assumptions hold.

The study was conducted for a period of one and a half months from mid-June 2019 to early July 2019. Data were collected through online questionnaires. A total of 246 questionnaires were collected, and contradictory questionnaires were screened out. A total of 14 invalid questionnaires, 232 valid questionnaires, and a valid questionnaire rate of $94.3 \%$.

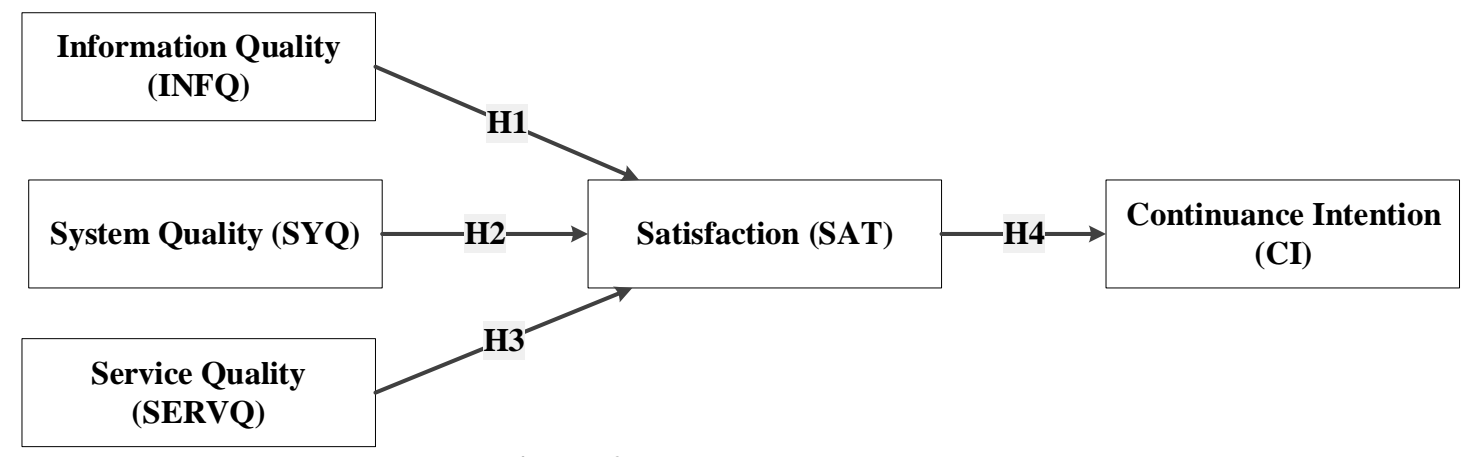

Figure 2: Research Framework

Table 2: Research Hypotheses

\begin{tabular}{ll}
\hline \multicolumn{1}{c}{ Hypothesis } & Path \\
\hline \hline H1: Information quality has the positive influence on satisfaction & INFQ -> SAT \\
\hline H2: System quality has the positive influence on satisfaction & SYQ -> SAT \\
\hline H3: Service quality has the positive influence on satisfaction & SERVQ -> SAT \\
\hline H4: Satisfaction has the positive influence on continuance intention & SAT -> CI \\
\hline $\begin{array}{l}\text { Note: CI= Continuance Intention; SAT= Satisfaction; INFQ= Information Quality; SYQ= System Quality; } \\
\text { SERVQ= Service Quality }\end{array}$ & \\
\hline
\end{tabular}

\section{Analysis Results}

In this study, Cronbach's $\alpha$ and composite reliability were used to test the reliability of each facet. As shown in Table 3, the reliability index of the five latent variables in this study is higher than 0.7 , which shows that the reliability of this study is acceptable.

Convergent validity, according to the proposed standards of Nunnally and Bernstein (1994) and Bagozzi and Yi (1988), the Composite Reliability (CR) to be tested for convergence validity should be greater than 0.70; the Average Variance Extracted (AVE) should be greater than Hair et al. al. (2010) suggested a value above 0.50. 
Table 3: Reliability and Convergent Validity

\begin{tabular}{cccc}
\hline Latent Variables & $\begin{array}{c}\text { Cronbach's } \\
\text { Alpha }\end{array}$ & $\begin{array}{c}\text { Composite } \\
\text { Reliability }\end{array}$ & $\begin{array}{c}\text { Average Variance } \\
\text { Extracted (AVE) }\end{array}$ \\
\hline CI & 0.961 & 0.961 & 0.892 \\
SAT & 0.889 & 0.890 & 0.730 \\
INFQ & 0.922 & 0.923 & 0.707 \\
SYQ & 0.910 & 0.910 & 0.773 \\
SERVQ & 0.902 & 0.905 & 0.707 \\
\hline
\end{tabular}

Note: $\mathrm{CI}=$ Continuance Intention; $\mathrm{SAT}=$ Satisfaction; INFQ= Information Quality; SYQ= System Quality; SERVQ= Service Quality

The discriminant validity of this study uses cross-loadings comparison method.From the results in Table 4, the standardized factor loadings of each facet of this study are higher than the cross loadings. It is obvious that the data of this study have discriminant validity (Hair et al., 2016).

Table 4: Discriminant Validity

\begin{tabular}{cccccc}
\hline Constructs and Items & CI & SAT & INFQ & SYQ & SERVQ \\
\hline CI1 & $\mathbf{0 . 9 7 3}$ & 0.892 & 0.702 & 0.618 & 0.635 \\
CI2 & $\mathbf{0 . 9 5 7}$ & 0.878 & 0.700 & 0.604 & 0.646 \\
CI3 & $\mathbf{0 . 9 0 1}$ & 0.826 & 0.691 & 0.636 & 0.631 \\
SAT1 & 0.709 & $\mathbf{0 . 8 0 3}$ & 0.691 & 0.595 & 0.665 \\
SAT2 & 0.817 & $\mathbf{0 . 8 5 1}$ & 0.646 & 0.617 & 0.657 \\
SAT3 & 0.819 & $\mathbf{0 . 9 0 5}$ & 0.741 & 0.642 & 0.750 \\
INFQ1 & 0.646 & 0.702 & $\mathbf{0 . 8 6 5}$ & 0.662 & 0.693 \\
INFQ2 & 0.616 & 0.637 & $\mathbf{0 . 7 8 5}$ & 0.610 & 0.653 \\
INFQ3 & 0.540 & 0.618 & $\mathbf{0 . 7 6 2}$ & 0.658 & 0.673 \\
INFQ4 & 0.656 & 0.714 & $\mathbf{0 . 8 8 0}$ & 0.762 & 0.748 \\
INGQ5 & 0.641 & 0.733 & $\mathbf{0 . 9 0 3}$ & 0.749 & 0.787 \\
SYQ1 & 0.608 & 0.656 & 0.770 & $\mathbf{0 . 9 0 6}$ & 0.780 \\
SYQ2 & 0.534 & 0.586 & 0.679 & $\mathbf{0 . 8 0 9}$ & 0.767 \\
SYQ3 & 0.583 & 0.664 & 0.713 & $\mathbf{0 . 9 1 7}$ & 0.842 \\
SERVQ1 & 0.507 & 0.550 & 0.530 & 0.679 & $\mathbf{0 . 7 5 1}$ \\
SERVQ2 & 0.595 & 0.698 & 0.755 & 0.820 & $\mathbf{0 . 8 6 2}$ \\
SERVQ3 & 0.601 & 0.723 & 0.759 & 0.731 & $\mathbf{0 . 8 9 2}$ \\
SERVQ4 & 0.566 & 0.737 & 0.777 & 0.763 & $\mathbf{0 . 9 1 1}$ \\
\hline
\end{tabular}

Note: CI= Continuance Intention; SAT= Satisfaction; INFQ= Information Quality; SYQ= System Quality; SERVQ= Service Quality

This study uses SmartPLS 3.2.9 (Ringle et al., 2019) software for hypothesis detection.In this study, the relationship between the facets of each other is based on the two-tailed test critical $t$ value $=1.96$ as the test criterion. A t value above 1.96 indicates that there is a significant direct positive effect ( $\mathrm{p}$-value $<0.05$ ). The results of the path analysis are shown in Figure 3.

According to the results of SmartPLS's path verification, the use of Digital Library Service is mainly directly affected by information quality and service quality.Through satisfaction, users will also be willing to continue to use the Digital Library Service due to the improvement of information quality and service quality. 


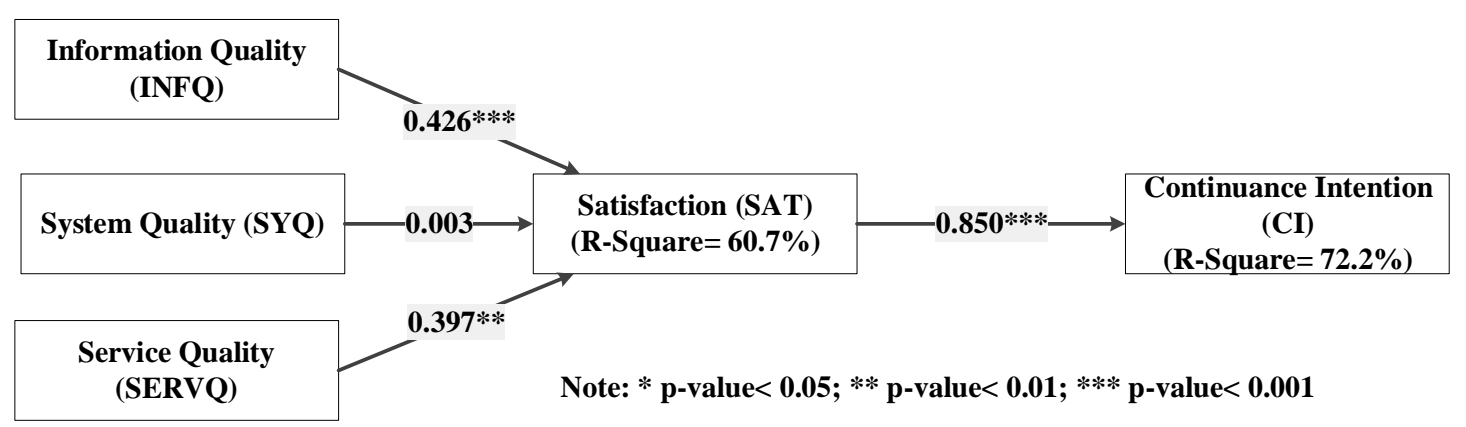

Figure 3: Path analysis and significance level

\section{Discussion and Conclusion}

The convenience of information technology has greatly changed the life style of modern society, and of course it also includes university libraries.More and more university libraries, the original paper-based collections, have also been adjusted to electronic resources-based services

Based on the conclusions of the study, several research suggestions are put forward here.For Chinese university libraries, there is an opportunity to learn more about the information systems of other libraries and supplement the functions of existing information systems in order to meet the increasingly high standards of information and service quality requirements.For subsequent researchers, if they are interested in this research topic, other possible environmental impact factors can be discussed.In addition, this research takes the information system success model as the theoretical basis for research, and subsequent researchers can also try to use other different theories to explore the quality of university library information systems.In addition, users' satisfaction with the use of the system and the benefits of use have always been important issues of concern to the practical community. Therefore, how to improve the user's satisfaction with the use of information systems has become a key issue.

In the past, the measurement of the use of information systems has mostly been based on system functions (for example, system usefulness, system ease of use, system quality, information quality, etc.).However, the use of information technology to improve the convenience and efficiency of life and work is not merely determined by the built-in functions of the system. Users can only react and accept passively. In fact, individuals have different values, personalities, abilities, attitudes, and motivations, and the use of the system will be affected by the cultural context, task structure, and social relationships of the users.Therefore, for the evaluation of information systems, related research in the future should also include factors such as user personal and social.

\section{References}

Aldholay, A. H., Isaac, O., Abdullah, Z., \&Ramayah, T. (2018). The role of transformational leadership as a mediating variable in DeLone and McLean information system success model: The context of online learning usage in Yemen. Telematics and Informatics, 35(5), 1421-1437.

Almutairi, H., \& Subramanian, G. H. (2005). An empirical application of the DeLone and McLean model in the Kuwaiti private sector. Journal of Computer Information Systems, 45(3), 113-122.

Angelina, R. J., Hermawan, A., \&Suroso, A. I. (2019). Analyzing E-Commerce Success using DeLone and McLean Model. Journal of Information Systems Engineering and Business Intelligence, 5(2), 156-162.

Bagozzi, R. P., \& Yi, Y. (1988). On the evaluation of structural equation models. Journal of the Academy of Marketing Science, 16(1), 74-94.

Bailey, J. E., \& Pearson, S. W. (1983). Development of a tool for measuring and analyzing computer user satisfaction. Management Science, 29(5), 530-545.

Bernroider, E. W. (2008). IT governance for enterprise resource planning supported by the DeLone-McLean model of information systems success. Information \& Management, 45(5), 257-269.

Chen, C. W. D., \& Cheng, C. Y. J. (2009). Understanding consumer intention in online shopping: a respecification and validation of the DeLone and McLean model. Behaviour\& Information Technology, 28(4), 335-345.

Delone, W. H., \& McLean, E. R. (2003). The DeLone and McLean model of information systems success: a tenyear update. Journal of Management Information Systems, 19(4), 9-30.

Doll, W. J., \&Torkzadeh, G. (1988). The measurement of end-user computing satisfaction. MIS Quarterly, 259274.

Doll, W. J., Xia, W., \&Torkzadeh, G. (1994). A confirmatory factor analysis of the end-user computing satisfaction instrument. MIS Quarterly, 453-461.

Eppler, M. J., \&Muenzenmayer, P. (2002). Measuring Information Quality in the Web Context: A Survey of Stateof-the-Art Instruments and an Application Methodology. In ICIQ (pp. 187-196).

Galletta, D. F., \& Lederer, A. L. (1989). Some cautions on the measurement of user information satisfaction. Decision Sciences, 20(3), 419-434. 
Ghazal, S., Aldowah, H., Umar, I., \&Bervell, B. (2018). Acceptance and satisfaction of learning management system enabled blended learning based on a modified DeLone-McLean information system success model. International Journal of Information Technology Project Management, 9(3), 52-71.

Gorla, N., \& Lin, S. C. (2010). Determinants of software quality: A survey of information systems project managers. Information and Software Technology, 52(6), 602-610.

Gorla, N., Somers, T. M., \& Wong, B. (2010). Organizational impact of system quality, information quality, and service quality. The Journal of Strategic Information Systems, 19(3), 207-228.

Gorla, N., Somers, T. M., \& Wong, B. (2010). Organizational impact of system quality, information quality, andservice quality. The Journal of Strategic Information Systems, 19(3), 207-228.

Guynes, C. S., \& Pelley, L. (1993). Monitoring database performance in an end user environment. Journal of Systems Management, 44(8), 27-32.

Hair Jr, J. F., Hult, G. T. M., Ringle, C., \&Sarstedt, M. (2016). A primer on partial least squares structural equation modeling (PLS-SEM). Sage Publications.

Hair, Jr., J. F., Black, W. C., Babin, B. J., and Anderson, R. E., (2010). Multivariate Data Analysis: A Global Perspective (7th ed.). Pearson Education International.

Hariguna, T., Lai, M. T., \& Chen, S. C. (2016). An Empirical Study on the Impact of Information System Quality on Software as a Service. Global Business \& Management Research, 8(3), 43-54.

Himang, M. M., Mendoza Jr, E., Manalastas, R., Ocampo, L., \&Himang, C. M. (2019). Modeling the Success of Windows Domain Network (WDN) Using the DeLone and McLean Information System (IS) Success Model: A University Case. International Journal of Sociotechnology and Knowledge Development (IJSKD), 11(3), 30-55.

Ives, B., Olson, M. H., \& Baroudi, J. J. (1983). The measurement of user information satisfaction. Communications of the ACM, 26(10), 785-793.

Jeong, M., \& Lambert, C. U. (2001). Adaptation of an information quality framework to measure customers' behavioral intentions to use lodging Web sites. International Journal of Hospitality Management, 20(2), 129-146.

Khayun, V., Ractham, P., \&Firpo, D. (2012). Assessing e-excise sucess with Delone and Mclean's model. Journal of Computer Information Systems, 52(3), 31-40.

Long, M., \&McMellon, C. (2004). Exploring the determinants of retail service quality on the Internet. Journal of Services Marketing, 18(1), 79-90.

Mardiana, S., Tjakraatmadja, J. H., \&Aprianingsih, A. (2015). DeLone-McLean information system success model revisited: the separation of intention to use-use and the integration of technology acceptance models. International Journal of Economics and Financial Issues, 5(1S), 172-182.

McKinney, V., Yoon, K., \& Zahedi, F. M. (2002). The measurement of web-customer satisfaction: An expectation and disconfirmation approach. Information Systems Research, 13(3), 296-315.

Nunnally, J. C., \& Bernstein, I. H. (1994). Psychological Theory.

Ojo, A. I. (2017). Validation of the DeLone and McLean information systems success model. Healthcare informatics research, 23(1), 60-66.

Parasuraman, A., Zeithaml, V. A., \& Berry, L. L. (1988). Servqual: A multiple-item scale for measuring consumer perc. Journal of Retailing, 64(1), 12-40.

Pitt, L. F., Watson, R. T., \&Kavan, C. B. (1995). Service quality: a measure of information systems effectiveness. MIS Quarterly, 173-187.

Rai, A., Lang, S. S., \& Welker, R. B. (2002). Assessing the validity of IS success models: An empirical test and theoretical analysis. Information Systems Research, 13(1), 50-69.

Ringle, C. M., Wende, S., \& Becker, J. M. (2019). SmartPLS 3.2.9. Boenningstedt: SmartPLS GmbH, http://www.smartpls.com.

Seddon, P. B. (1997). A respecification and extension of the DeLone and McLean model of IS success. Information systems research, 8(3), 240-253.

Sigwart, C. D., Hansen, J. C., \& Meer, G. L. V. (1990). Software Engineering: a project oriented approach. Franklin, Beedle \& Associates Inc.

Tayi, G. K., \& Ballou, D. P. (1998). Examining data quality. Communications of the ACM, 41(2), 54-57.

Thong, J. Y., Hong, W., \& Tam, K. Y. (2002). Understanding user acceptance of digital libraries: what are the roles of interface characteristics, organizational context, and individual differences?. International Journal of Human-computer Studies, 57(3), 215-242.

Wang, R. Y., \& Strong, D. M. (1996). Beyond accuracy: What data quality means to data consumers. Journal of Management Information Systems, 12(4), 5-33.

Wang, Y. S., \& Liao, Y. W. (2008). Assessing eGovernment systems success: A validation of the DeLone and McLean model of information systems success. Government Information Quarterly, 25(4), 717-733.

Wei, K. M., Tang, Y. T., Kao, Y. C., Tseng, L. C., \& Wu, H. H. (2017). Using an updated Delone and McLean model to assess the success of implementing the ward cleaning logistics system in a medical center. Journal of Statistics and Management Systems, 20(5), 965-976. 